\title{
The EU and the Defense of Democratic Values
}

\author{
Lucio Levi
}

Jean-Claude Juncker opened his speech on the State of the Union on a note of optimism. "Wind is in our sails", he said. After Brexit, the victory of pro-European parties in political elections in France and Germany and President Macron's important speech at the Sorbonne on "the rebuilding of a sovereign, democratic and united Europe", conditions seem to be ripe for resuming the march towards federal union. But there is no absolute certainty. If that way will not be followed, the EU's disintegration, that is already underway, will lead to the end of the European integration experiment.

The fundamental contradiction of our time lies in the gap between the economy, that has become global, and politics, that remains national. The wave of globalization produces a toxic combination of two negative elements: the retreat of the state and the growing power of global finance and multinational corporations. As a matter of fact, states have abdicated their responsibility to regulate globalization and allowed market forces to gain the upper hand over politics. They are like failed corporations put into receivership by the new world order dominated by non state actors. In other words, power has migrated from the organizations that ensure public goods to those primarily oriented towards profit and private interest.

Margaret Thatcher's prophecy of a deregulated society is fulfilled. But the result is not freedom, peace and prosperity. Unlike her expectations, the power vacuum produced by the retreat of the state generates the loneliness of the citizen and spreads fear. The fall of collective reference points paves the way to unbridled violence and arouses a sense of precariousness. The fading of state's authority generates monsters like terrorism, xenophobia, racism and revives old nightmares like the atomic bomb.

Unregulated globalization has created deep imbalances both within states and among states. Inequality between the richest $1 \%$ and the rest of the world is widening, since, according to a study by Oxfam, the $99 \%$ of the world's population possesses as much wealth as the $1 \%$. The rich countries in 1960 the end of colonialism - were 33 times richer than the poorest countries, while in 2016, according to World Bank figures, the gap for Latin America has grown to $306 \%$, for subSaharan Africa to 307\% and for South Asia to $296 \%$. In other words, the gap has tripled. Moreover, the decisions taken at national level, where democratic institutions survive, are by now second-rate decisions, while at international level, where the most important decisions are taken, there are no democratic institutions. The goals of public good and general interest are pushed to the margins of political life and sacrificed to private interests. The risk that we have to face is that democracy becomes an empty shell. We have to ask ourselves for how long democracy will last in a world in which citizens are excluded from participating in decisions that determine their fate. International organizations, first of all the 
UN, but also the WTO, the WB and the IMF should be strengthened and subjected to democratic control. Globalization must be democratized before it destroys democracy. In the cycle of world politics begun after the financial and economic crisis, the main political divide is between the forces of nationalism and the forces of globalism. Trump's nationalism should not be interpreted as a reassertion of the American power in the world. It is rather the expression of a US retreat from global leadership and a renunciation to play the role of flag-bearer of liberal-democracy. This is the meaning of the US withdrawal from the Paris climate deal and from UNESCO, its attack on free trade agreements, NAFTA included, its threat to abandon the multilateral nuclear deal with Iran and its plan to build a wall along the US-Mexico border. On the other hand, the US is not willing to continue to bear the burden of the defense of Europe, a region that is as rich as the US.

This program sounds like a challenge for Europe. Taking into account that Russia, India and China have made appeals to nationalism, the EU remains the only advocate of Western values. In his speech at the UN General Assembly, Macron opposed an alternative view of the future of the world, based on the principle that global challenges should be addressed at global level, otherwise the law of the strongest is destined to prevail. The European historical experience shows that there is a close relationship between nationalism and the two World Wars. Provided that it acquires the power to make an impact on global politics through federal union, the EU can become a promoter of freedom, democracy, the rule of law and the dignity of human beings worldwide. In areas in which the EU has exclusive competences, such as monetary and commercial policies, it can speak with one voice, can behave more or less like a federal union and can have an impact on world politics. But also in other areas in which member states can act together, as pointed out by the Paris agreements on climate change and the nuclear deal with Iran, the EU can shape the global agenda.

Furthermore, the fundamental weakness of the EU lies in the frailty of its power of the purse and the sword, the core powers of any government, which allow to control budget and taxation, on the one hand and army and police, on the other hand. In fact, the European budget amounts only to $1 \%$ of the European GDP and the Eurocorps numbers approximately 60,000 troops.

If market is global, why political power and democratic representation remain confined within national barriers? Federalism at the macro-regional and global levels can provide a response to this question in terms of effectiveness (a multilevel government enables to articulate political power at several levels of government from the local community to the world) and democracy (international democracy according to the model of the European Parliament). It is a political formula that enables to extend democracy and the rule of law beyond national borders.

In the areas in which the EU has got powers to act at international level it can have an impact on global affairs. Firstly, it can act for strengthening the WTO in order to allow it to govern globalization and endow it with an antitrust authority and a taxation power. Secondly, there is a plan to award to the Eurozone countries a single seat in the IMF by 2025. This is a condition for strengthening the Chinese plan aiming to replace the US dollar with the Special Drawing Rights (SDR), a basket of key international currencies, that recently has been extended to the renminbi. The goal is to build a more stable and equitable monetary 
system. Thirdly, the adoption by the EU of a carbon tax and a financial transactions tax could pave the way to the extension of these taxes to other regions of the world and at world level. Fourthly, if the EU endows itself with common security forces and a defense system (the procedure to reach that goal will start by the end of this year), it could commit itself to transform the UN Security Council into the Council of the great regions of the world. In fact, the most serious shortcoming of the UN lies in the enormous disparity Member of the Federal Committee of UEF in size and power of its member states. Therefore, regional groupings of states are necessary to improve the structure of the UN and make its working more efficient, just and democratic. As Germany sacrificed the Deutsche Mark to the euro, likewise France could share its own seat in the Security Council with its EU partners. Lastly, the European model of international democracy could help promote the creation of a UN Parliamentary Assembly, conceived as a step towards a World Parliament. 